\title{
Erratum to: The burden of smoking in Israel-attributable mortality and costs (2014)
}

\author{
Gary M. Ginsberg ${ }^{1 *}$ and Haim Geva ${ }^{2}$
}

After publication of this study [1], the authors noticed an error in the Conclusions. It should be 3600 million NIS instead of 3.6 million NIS. Please see the correct Conclusions below:

\section{Conclusions}

Smoking causes a considerable burden in Israel, both in terms of the expected 7847 lives lost and the financial costs of around 3600 million NIS (\$1030 million or $0.42 \%$ of GNP).

\section{Author details}

'Medical Technology Assessment Sector, Ministry of Health, Jermiahu 39, Jerusalem 9446724, Israel. ${ }^{2}$ Department of Health Promotion, Ministry of Health, Jerusalem, Israel.

Received: 21 January 2016 Accepted: 5 February 2016

Published online: 10 February 2016

\section{Reference}

1. Ginsberg GM, Geva H. The burden of smoking in Israel-attributable mortality and costs (2014). Isr J Health Policy Res. 2014;3:28.

\footnotetext{
* Correspondence: gary.ginsberg@moh.health.gov.l

'Medical Technology Assessment Sector, Ministry of Health, Jermiahu 39, Jerusalem 9446724, Israel

Full list of author information is available at the end of the article
}

Submit your next manuscript to BioMed Central and we will help you at every step:

- We accept pre-submission inquiries

- Our selector tool helps you to find the most relevant journal

- We provide round the clock customer support

- Convenient online submission

- Thorough peer review

- Inclusion in PubMed and all major indexing services

- Maximum visibility for your research

Submit your manuscript at www.biomedcentral.com/submit

\section{() Biomed Central}

